\title{
避難計算のための群集歩行シミュレーションモデルの 研究とそれによる避難安全性の評価 \\ A STUDY OF SIMULATION MODEL FOR PEDESTRIAN MOVEMENT IN FIRE ESCAPE AND EVALUATION OF FIRE SAFETY OF PLANS BY IT
}

\author{
岡崎甚幸*, 松下 聡** \\ Shigeyuki OKAZAKI and Satoshi MATSUSHITA
}

\begin{abstract}
This is a proposal of an application method of simulation model for pedestrian movement to evaluation of building plans regarding fire escape. The model can visualize the movement of each pedestrian in building plans, so designers can easily find problems of plans to improve them. 11 examples of simulation show that this model is available for evaluation of fire safety of plans as well as existing calculation method, and that the model is available for other problems like changes of coefficient of pedestrian flow and change of path. The accuracy of the model is confirmed by experiments of pedestrian movement.
\end{abstract}

Keywords : fire escape, simulation model, stagnation, coefficient of pedestrian flow, path 避難, シミュレーションモデル，滞留，流動係数，歩行経路

\section{序}

防災評定では、新・建築防災計画指針」”に基づく避 難計算（以後「防災評定避難計算」之呼ぶ）が，建物の 避難安全の評価・検討に用いられている。文献 2)によ ると，この計算は，避難行動予測手法の分類上「評価・ 検討型」と呼ばれている。この型の定義は「特定の計画 または実体に対して避難の状況, 特に群集流動状況を予 測し, 避難安全の評価・検討を行うもの」である。これ に対して著者達の電算機による「群集歩行シミュレー ションモデル」31-8) はそこでは「特性解析型」と呼ばれ, 「特定の建物を対象とせず，主として建物の一部を取り 上げて詳細なモデルを組立て, 行動の理論的な原理を解 明しょうとするもの」と定義されている。

また文献 2）は防災評定避難計算に対するものとして トランザクション法およびその他を挙げ，トランザク ション法の中に座標モデル, 経路モデル,メッシュモデ ルを挙げている。著者達の「群集歩行シミュレーション モデル」は座標モデルに位置づけられているが, 複雑な 経路を認知し，それに従って避難できる経路モデルとし ての機能も備えている。

この群集歩行シミュレーションモデルによって防災評
定避難計算之同一条件で，与えられた平面上でシミュ レーションを行い，防災評定避難計算の結果およびその ほかの以下に述べる種々の検討が可能であることを示 す。防災評定避難計算で行っている数値計算とグラフに よる避難特性の表現ではなく, 個々の避難者の行動を 時々刻々画面上に表示し，建築空間の全体的・部分的な 避難特性を視覚的に把握可能にする。またシミュレ一 ション結果から，必要な任意の時刻における出入口や通 路の流動係数や歩行速度が測定可能なので，プログラム が正常に動作しているか否かを容易に検討できる。

このモデルによると防災評定避難計算で行われる避難 時間と滞留人数の検討以外に以下の問題に対しても検討 が可能である。

1）群集の流動係数は一定の值ではなく，種々の理由に より低下し，それが避難時間の增大につながる。

2）避難途中での歩行者の滞留や交差流の検討。

3）防災評定避難計算で設定されている避難経路とは別 の新しい避難経路の検討。

特に1）の流動係数の低下に関しては，種々の状況下 で歩行実験を行い，実際の群集歩行とシミュレーション 結果が一致することを確認する。そして滞留密度の形成
* 福井大学工学部環境設計工学科 教授. 工博

** 福井大学工学部環境設計工学科 助教授・工博
Professor, Dept. of Architecture and Civil Engineering, Faculty of Engineering, Fukui Univ., Dr. Eng.

Associate Professor, Dept. of Architecture and Civil Engineering, Faculty of Engineering, Fukui Univ., Dr. Eng. 
のされ方，群集歩行密度の形成のされ方，群集歩行密度 (滞留密度) の值やそれと歩行速度の関係がシミュレー ションと実際の調查 ${ }^{9}$ とで良く一致していることを示 す。つまり，与えられた平面図の上で，避難上危険ない かなる行動が，いかなる場所で発生するか，あるいは平 面全体でいかなる避難経路を設定するのが合理的なのか などを解明するのに役立ち，設計へのフィードバック ${ }^{101}$ に適している。

この方法は何よりも分かりやすく，それ故説得力があ る。しかし現行の簡便な計算方法に取って代わろうとす るものではない。ここでは，このような手法の潜在的な 可能性を述べるに止め，これを実際に指針化，あるいは 基準化するか否かは行政その他の判断にゆだねる。

\section{1.「新・建築防災計画指針」による避難計算方法の概要}

「新・建築防災計画指針」で述べられている避難計算 方法では以下の仮定に基づいて，避難時間，滞留人数を 計算し，建物の避難安全性を評価する。

1.1 避難計算方法の仮定

避難計算は以下の仮定を前提として行われる。

1) 避難対象者は室内に均等に分布している。

2）同一室内の避難はいっせいに開始される。出火室の 避難開始時間は $2 \sqrt{A}$, 他の室では $4 \sqrt{A}$ 。（ $A$ : 出火室 面積）

3）避難者はあらかじめ定められた経路を通って避難す る。

4）歩行速度は一定で，追い越しや逆戻りなどがない。

5）群集流動係数はあらかじめ決められている。

6）出入口が複数で特に誘導がない場合は最寄りの出入 口から退出。

\section{2 避難時間の計算}

3 通りの避難時間として, 居室避難時間（各居室ごと に，その室の全員が室外に避難完了するまでに要する時 間), 廊下避難時間（廊下などの第 1 次安全区画に避難 者が存在する時間の長さ), 階避難時間（火災発生時刻 からその階の全員が階段室または附室に避難完了するま での時間）を計算する。

\section{3 評価}

避難時間および滞留人数を以下のよおり評価する。

（1）避難時間の評価：上記各避難時間がそれぞれの許 容避難時間より小さいと避難は安全であるとみなされ る。居室, 廊下, および階許容避難時間はそれぞれ，「2 - 3 $\left.\sqrt{A_{1}}\right\rfloor,\left\lceil 4 \sqrt{A_{1}+A_{2}}\right\rfloor,\left\lceil 8 \sqrt{A_{1}+A_{2}}\right\rfloor て ゙ あ る 。 A_{1}$ は 出火室の面積, $A_{2}$ は非出火室の面積と廊下または第一 次安全区画の面積の合計である。

（2）滞留人数の評価：出入口などのネック部分の最大 滞留人数を計算し, 必要面積が確保されているかを評価 する。
隌下などの第一次安全区画の必要面積

$=$ 最大滞留人数 $\times 0.3\left[\mathrm{~m}^{2} /\right.$ 人 $]$

附室やバルコニー等の第二次安全区画の必要面積 $=$ 最大滞留人数 $\times 0.2\left[\mathrm{~m}^{2} /\right.$ 人 $]$

\section{2. 磁場モデルによる群集歩行シミュレーションモデル の概要}

\section{1 モデルの概要 ${ }^{3)-8)}$}

歩行者に正の磁極，壁や障害物にも正の磁極，各歩行 者の歩行目的地に負の磁極を与える。磁極はその種類に よって様々な磁場をその周辺に形成する。任意の歩行者 に働く力に比例して歩行者の新しい位置, 速度, 向きを 求める3!。各磁極が持つ磁荷の值が大きい場合は, 歩行 者と障害物間, 歩行者間に大きな反発力が働き, 歩行者 と障害物間, 歩行者間の距離が大きくなり, 全体として 歩行者密度が小さくなる。そのような磁場においてシ ミュレーションを行って流動係数を测定すると，小さい 値となる。磁荷の値が小さい場合は逆になる。この歩行 者, 障害物, 目的地などの磁荷の值を調節することによ り, 群集歩行の変化が起こり, そのシミュレーション結 果から測定される流動係数は変化する。

壁，独立柱，楋などの障害物は，歩行領域に対して時 計回りになるような壁面のベクトル $w_{i}$ の連続で与え る。すべての壁面の集合を $W$ とすると

$$
W=\left(w_{1}, w_{2}, \cdots w_{i}, \cdots w_{n}\right)
$$

任意の点 $m$ で互いに接続する任意の二つの壁ベクトル を $w_{i}, w_{j}$ とすると

$$
\begin{aligned}
& w_{i}=\left(\left(l_{x}, l_{y}\right),\left(m_{x}, m_{y}\right)\right) \\
& w_{j}=\left(\left(m_{x}, m_{y}\right),\left(n_{x}, n_{y}\right)\right)
\end{aligned}
$$

である。点 $m$ が歩行領域に対して凸になるとき点 $m$ をコーナーと呼ぶ。図一1のように，2つの壁ベクトル $w_{i}, w_{j}$ が点 $m$ において結合しているとき, 2 つのベク トルの成す角度を $\alpha$ とすると, 「 $\sin \alpha>0 」 の と き, ~ m$ はコーナーと見なされる。

このような点 $m$ の集合を $M$ とする。集合 $M$ 中の任 意の 1 組のコーナー $m_{i}, m_{j}$ の間を遮る壁面や障害物の 有無により， $m_{i}, m_{j}$ 間の隣接関係を以下のように定義 する。

$$
\begin{aligned}
& R\left(m_{i}, m_{j}\right)=1: \text { 隣接関係がある。 } \\
& \quad\left(m_{i}, m_{j} \text { 間を遮る壁面や障害物がない。 }\right) \\
& R\left(m_{i}, m_{j}\right)=0: \text { 隣接関係がない。 } \\
& \quad\left(m_{i}, m_{j} \text { 間を遮る壁面や障害物がある。 }\right)
\end{aligned}
$$

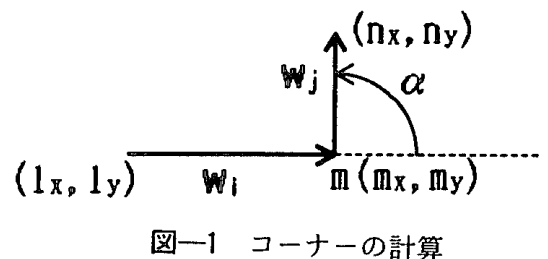


集合 $M$ から任意のコーナー $m_{i}$ を取り出し，次に， $R\left(m_{i}, m_{j}\right)=1$ となるコ一ナー $m_{j}$ を取り出す。さらに この手続きを繰り返し，新たに取り出したコーナーに隣 接するコーナーを順次取り出し，コーナーの列集合 $M_{\rho}$ を形成する。

$$
M_{p}=\left(m_{1}, \cdots m_{i}, \cdots m_{n}\right)
$$

このようなコーナーの列の最後に歩行者の目的地であ る出入口を加えたものを歩行経路とする。各歩行者はシ ミュレーション開始後, 目的地に通じる歩行経路上の任 意のコーナー $m$ を順次仮目的地とし，そのコーナー $m$ に負の磁極を仮想して,そこからの引力により歩行する。 コーナー $m$ に十分近づくと列中の次のコーナーを仮目 的地として歩行し, 最終的に目的地に到達する。集合 $M$ の中から列集合 $M_{p}$ を作るとき，その作り方によっ て,以下の各種の経路が形成される。

（1）指定経路 実験者が平面図を見て $M_{\rho}$ を指定する もの

（2）最短経路 Dijkstra の方法による出発点と最終目 標点との間の最短経路

(3) 探索経路8) シミュレーション中に各歩行者が指定 経路や最短経路を見失ったとき，一定 の規則に従ってもとの経路を探し続け るもの，あるいはシミュレーションの 最初から最後まで探索を続けるもの

(4) 誘導経路" 歩行空間内に誘導標を設定し上記各経 路と組み合わせて経路を作成し，それ にしたがって歩行するもの

防災評定の避難シミュレーションのためには指定経路 だけで十分であるが，当然その他の経路によるシミュ レーションも可能である。そのことによって多様な避難 経路の可能性を検討できる。

2.2 シミュレーションデータ

このシミュレーションモデルで用いるデータの主なも のは以下のとおりである。これらのデータを入力して, 単位時間ごとに平面上の各歩行者の位置, 速度, 向きを 計算し，計算機の画面上に歩行者を表示する。

\section{(1) 空間データ}

壁，独立柱，柵などの障害物のデータは壁面の集合 $W$ により構成される。

出入口のデータは集合 $M$ の中から相異なる壁に属す る 2 点 $m_{i}, m_{j}$ を結ぶ $E_{i}$ によって作られる。したがう て出入口の集合 $E$ は以下のとおりである。

$$
E=\left(E_{1} \cdots, E_{i}, \cdots E_{n}\right)
$$

目的地のデータは出入口の任意のものが目的地として 選ばれ,そこに歩行者が到達すると,その歩行者のシミュ レーションは終了する。

(2) 歩行者デー夕

歩行者は集団で入力される場合と個別に入力される場
合がある。数百人に及ぶ歩行者のデー夕を 1 人ずつ入力 することは不可能であるから一般的には集団入力を用い る。歩行者の全集団を $G$ ，その中の任意の集団を $G_{i}$ 之 すると

$$
G=\left(G_{1}, \cdots, G_{i}, \cdots G_{n}\right)
$$

任意の集団 $G_{i}$ は以下の特性を持つ。

$$
\begin{aligned}
& G_{i}=\left(N_{i}, F_{i}, V_{i}, T_{i}, S_{i}, A_{i}, M_{p_{i}}, D_{i}\right) \\
& N_{i}=\text { 集団構成人数 } \\
& F_{i}=\text { 磁力 } \\
& V_{i}=\text { 平均歩行速度 } \\
& T_{i}=\text { 歩行開始時間 } \\
& S_{i}=\text { 歩行開始領域 } \\
& A_{i}=\text { 歩行開始時の歩行者の向き } \\
& M_{p_{i}}=\text { 歩行経路 } \\
& D_{i}=\text { 歩行開始時の歩行者密度 }
\end{aligned}
$$

$G_{i}$ のデー夕はその構成員の $N_{i}$ 人の一人一人のデー夕 $P_{i}$ に自動的に変換される。集団内の各歩行者は以下の 特性を持つ。歩行者のデー夕を個別に入力するときはこ れらのデー夕を与える。

$$
\begin{aligned}
P_{i} & =\left(F_{i}, x_{i}, y_{i}, a_{i}, v_{i}, T_{i}, M_{\rho_{i}}\right) \\
F_{i} & =\text { 磁力 } \\
x_{i} & =\text { 歩行者位置の } X \text { 座標 } \\
y_{i} & =\text { 歩行者位置の } Y \text { 座標 } \\
a_{i} & =\text { 歩行者の向き } \\
v_{i} & =\text { 歩行速度 } \\
T_{i} & =\text { 歩行開始時間 } \\
M_{p_{t}} & =\text { 歩行経路 }
\end{aligned}
$$

各歩行者の歩行速度 $v_{i}$ は平均歩行速度を $V_{i}$ とし, 分 散 $=0.25$ の正規分布乱数により定められる。歩行開始 時の歩行者位置座標 $\left(x_{i}, y_{i}\right)$ は歩行開始領域内に一様 乱数により定められる。この場合他の歩行者との間隔が 小さすぎる場合は再度乱数を発生させ，発生密度を保つ ように各歩行者の位置を定める。歩行開始領域は居室の ゾーン分けされたものの一つ一つである。ゾーン中に乱 数によって歩行者が分散配置され，それぞれの場所から 避難開始する。歩行開始時の歩行者の向きは $A_{i}$ である が, 歩行途中では, 歩行経路上の目的地 $m_{i}$ の方向 $\left(a_{i}\right)$ に自動的に調節される。歩行者の磁力 $F$ は全員同じ値 を持つ。歩行開始時間 $T$ および歩行経路 $M_{p_{i}}$ は同一集 団内の歩行者に共通の值を持つ。

したがって，この方法では防災評定避難計算のように 流動係数, 歩行距離, 出入口幅などを入力する必要はな い。

\section{3 - 避難時間の抽出}

シミュレーション実行中に，ある歩行者がいずれかの 出入口を通過したら, その「歩行者番号」,「時刻」,「出 入口番号」が記録される。このデータを参照することに より，指定された任意の出入口に関して最初と最後に歩 
行者が通過した時刻を即座に求めることができる。これ を用いてシミュレーション結果の 3 通りの避難時間を以 下の方法で容易に計算できる。

居室避難時間 $=T_{11}-T_{10}$

$T_{10}:$ そ居室の避難開始時間

$T_{11}$ ：居室の出口を歩行者が鼠後に通過した時間 廊下避難時間 $=T_{21}-T_{20}$

$T_{20}$ ：廊下に面する居室の出入口から最初の歩行 者が廊下に流入した時間

$T_{21}$ : 最後の歩行者が階段室に流入した時間 階避難時間 $=T_{3}-T_{0}$

$T_{0}:$ 火災発生時刻

$T_{3}$ : 最後の歩行者が階段室に流入した時間 上記の避難時間計算以外にも，以下のような項目が容易 に計算でき, 群集の歩行または滞留状況を視覚的に把握 するほか，数量的にも確認することができる。

任意の出入口における任意の時間間隔内の流動係数 任意の歩行者の歩行速度

平面上の任意の部分の歩行者密度および人数

2.4 シミュレーションのフロー

磁場モデルによるシミュレーションモデルの全体構成 は図一2のフローチャートのとおりである。

3. 群䶂歩行モデルによる避嚾シミュレーション

本論で提案している群集歩行シミュレーションモデル により，EX 1 EX 11 の 11 通りの平面に関して避難行 動のシミュレーションを行った。まずその中から, 代表 的な例を 3 通り提示し, 防災評定避難計算の結果と比較 し, 防災評定避難計算で行われている避難時間, 滞留人

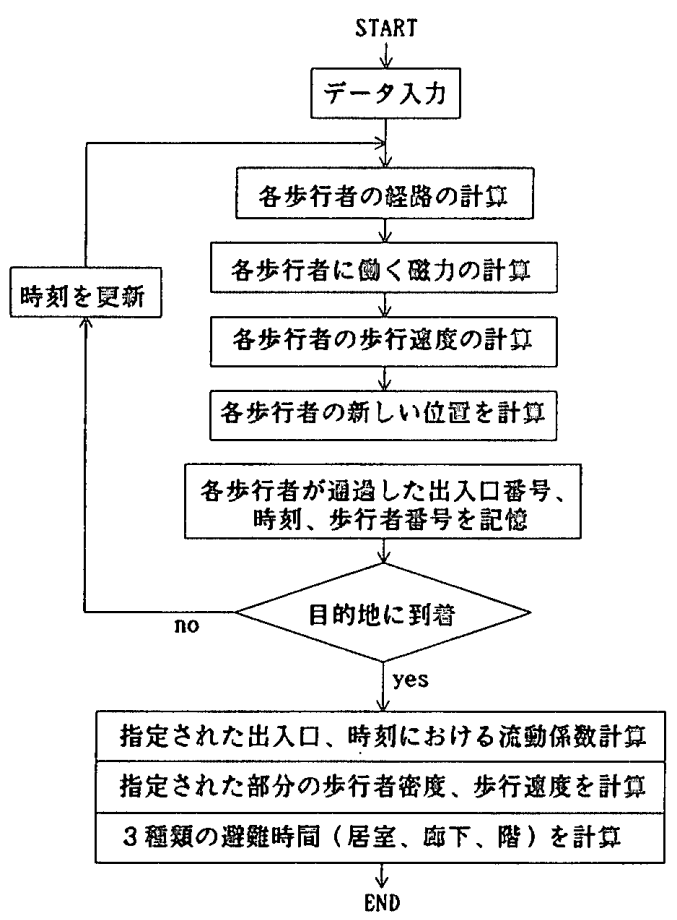

図一2 シミュレーションモデル全体のフローチャート
数の検討などに有効であることを示し，モデルの実用性 を示す。さらに，防災評定避難計算では十分に現れない が，シミュレーションにより発見された問題点として以 下のようなものが挙げられる。

1）流動係数は防災評定避難計算では一定として扱われ ているが，状況により変化する場合が見られる。

2）滞留の発生および, 滞留のための有効面積の問題。

3）避難経路の問題。防災評定避難計算では最奇りの出 口から避難することとなっているが，場所により，避難 時間や滞留人数に著しい片寄りを生じ, 非現実的な現象 が生じる場合がある。

これらの問題点に関して, 確認のために行った実際の 歩行実験結果も交えて述へ，より多様な問題の検討に対 する有効性を示す。

\section{1 シミュレーション例}

避難シミュレーションを表一 1 , 表一 2 に示す 11 通り

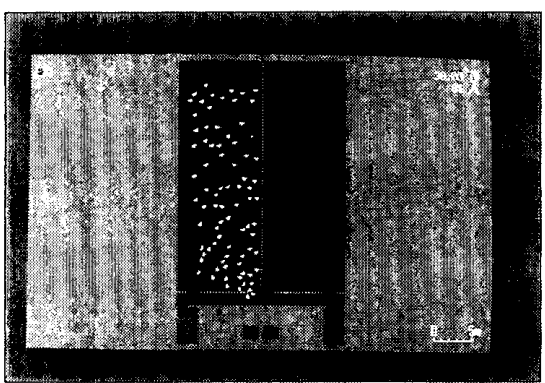

38. 00

火炎陉生室加步行者加 36.

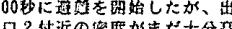

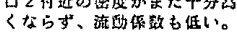

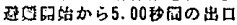

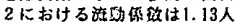

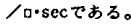

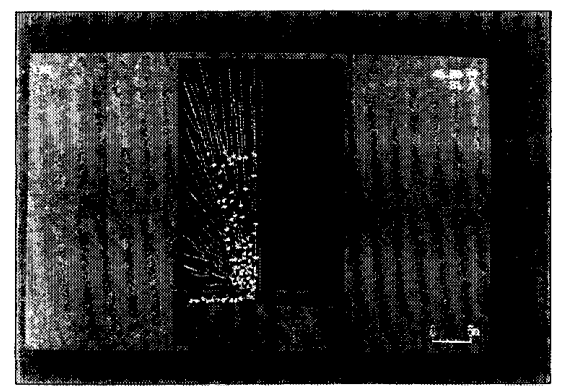

45. 00 杪

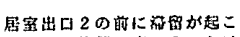
つている状出。出口2におけ

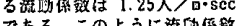

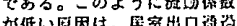

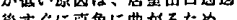
篎行积度加低下し、そのため

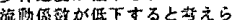
ns。

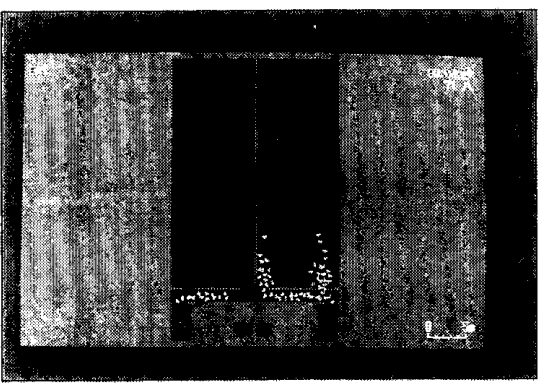

90.001

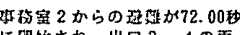
に坮され、出口3，40承

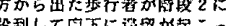
促。

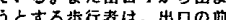

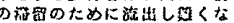
出ている。

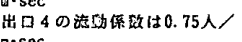
$\mathrm{a} \cdot \mathrm{sec}$

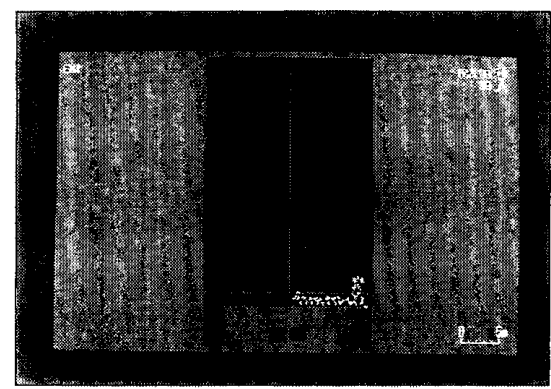

102. 00 歽

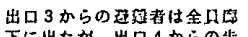
下に出た汃、出口 4 如らの悲

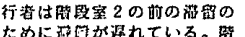

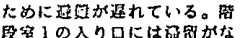
段公1の人り口下は活留かな くなっていので、刵突には、

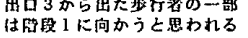

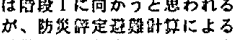
避嚾路の设定ては、この 避全的股 2 に向办う。 


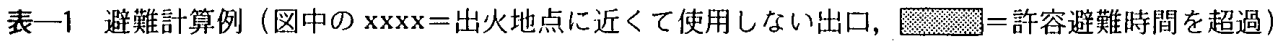

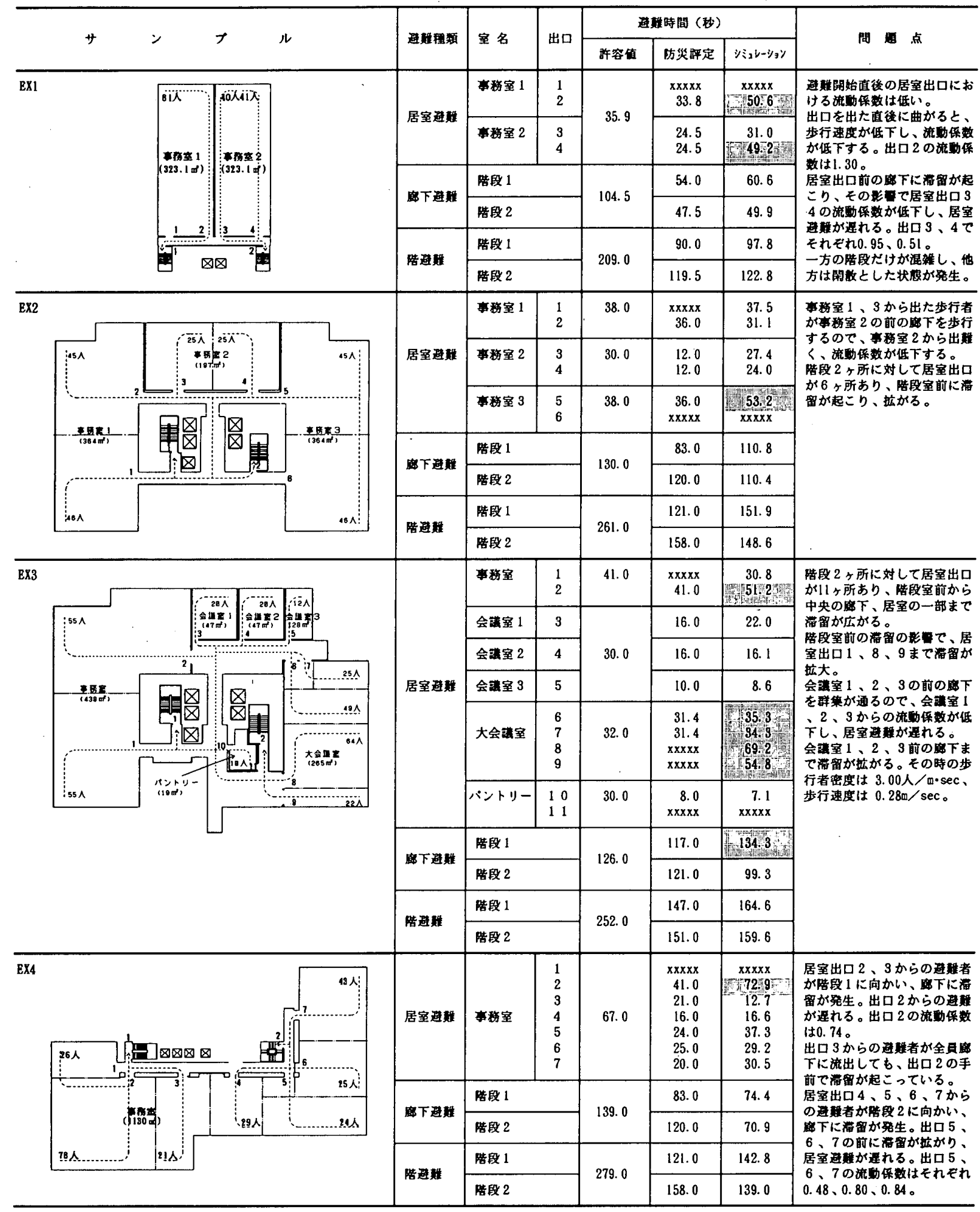

行った。その中から問題点が顕著に現れた例を 3 通り示 す(図一3-5)。いずれも火災発生㭙刻は 0.0 秒とし, 避難者数, 避難経路などの条件は「新・建築防災計画指 針」に基づいて設定している。これらのシミュレーショ ンは NEC PC 9801 RA を用いて行い, 100 人前後の歩 行者の避難計算所要時間は, 1 時間程度であった。歩行 者数の上限は現在 1000 人としている。
以上の 3 例のほか，この群集歩行シミュレーションモ デルにより奏行したシミュレーション結果と, 防災評定 避難計算結果を比較し, 問題点をまとめたものが表一1, 表一2である。

\section{2 諸々の理由による流動係数の低下の問題}

ここでは流動係数は出入口通過前後において歩行方向 に変化がない場合に防災計画指針に定められた約 1.5 人 


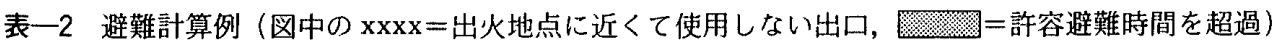

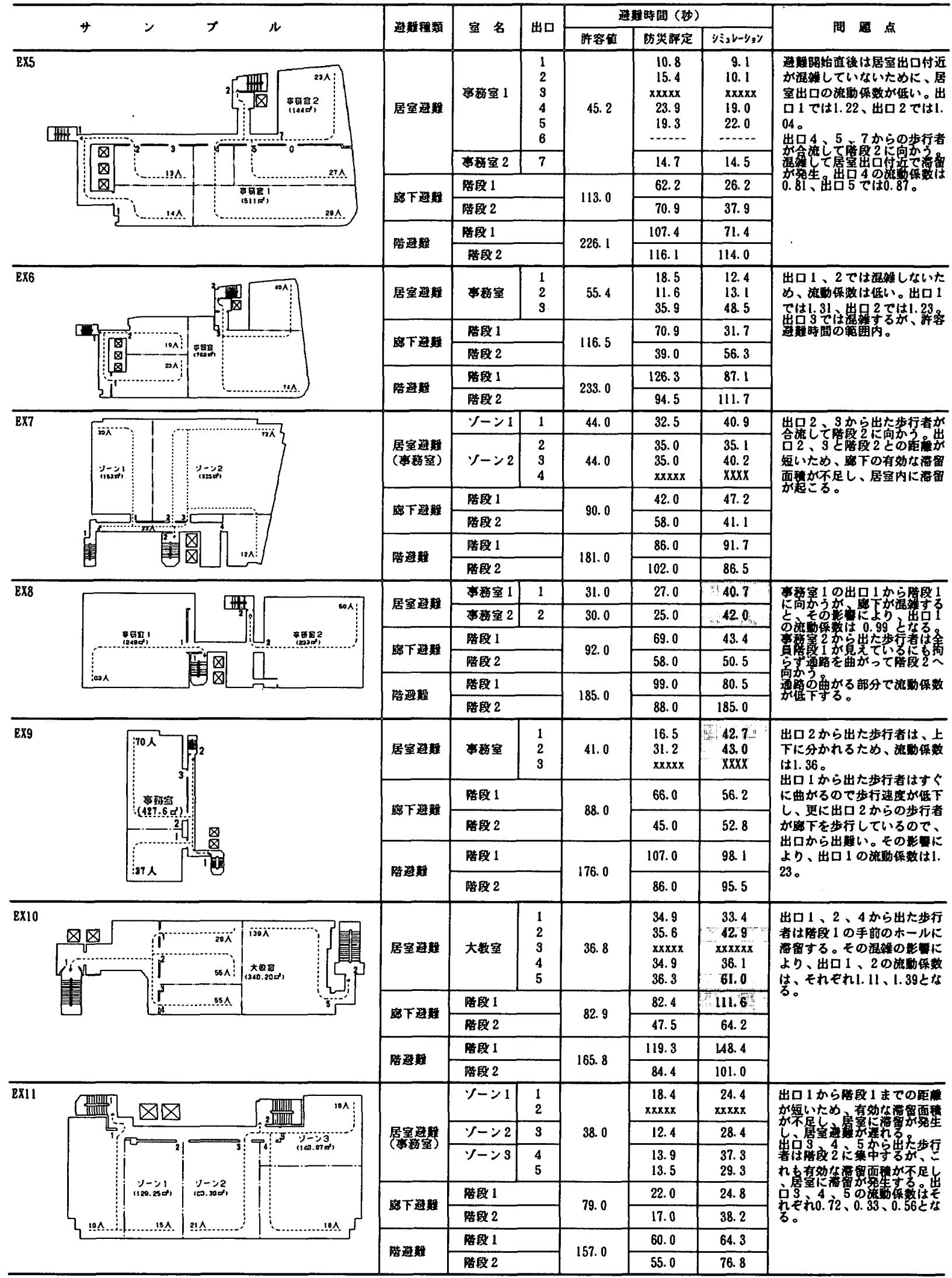

$/ \mathrm{m} \cdot \sec$ となるように，モデル中の歩行者や障害物の磁 荷を設定してある。また歩行速度は平均 $1.3 \mathrm{~m} / \mathrm{sec}$, 分散 $=0.25$ の正規分布としている。ところが以下のよ うな諸条件によって流動係数が低下し，居室避難時間が
長くなることが，シミュレーション結果により判明し， 実際の歩行実験を行いそれを確認した。その結果再び 種々の建築空間において避難行動のコンピューターシ ミュレーションを行い，下記の状況が原因で，防災評定 


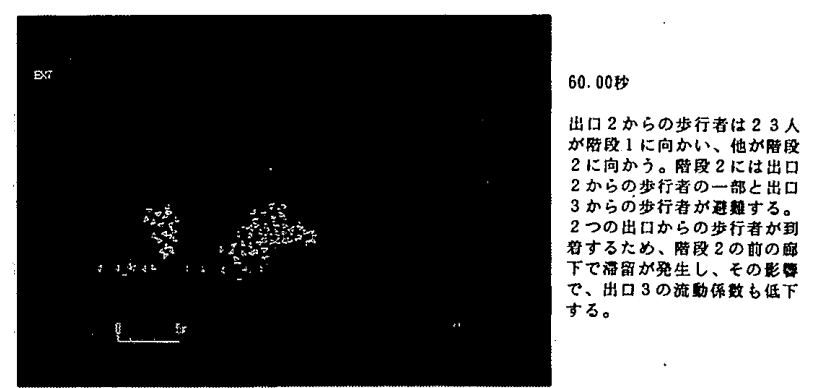

图一4 シミュレーション例 (EX 7)

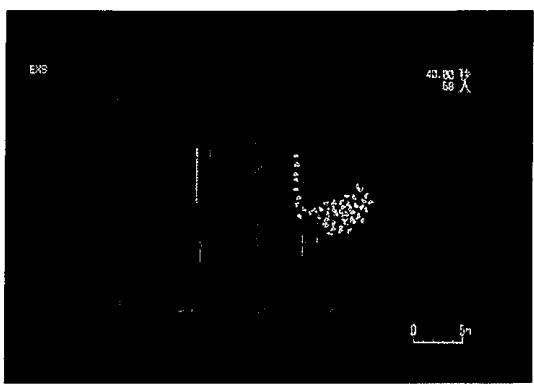

40.00\%

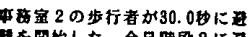

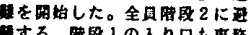

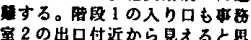

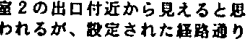

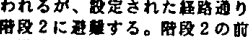

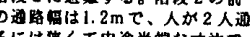

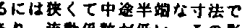

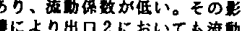

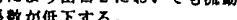

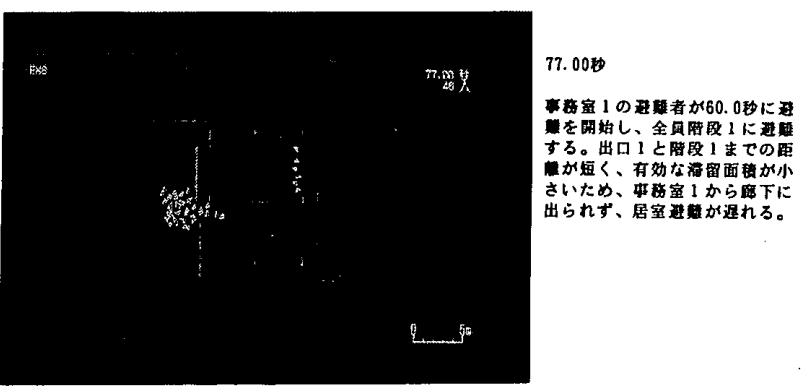

图一5 シミュレーション例（EX 8)

の許容避難時間を越える避難時間を要する場合もあるこ とを示す。

（1）広い居室で避難開始後しばらくは出口への到達者 が少ないため, 流動係数が 1.5 人/m.secに達しない状 況がしばらく続く。これに対して防災評定避難計算では, 避難開始直後といえよ゙も出入口における流動係数は一定 の值になっている。[例 EX 1 (38.00 秒), EX 2, EX 10] （2）出入口通過後に折れ曲がることによる流動係数低 下

群集歩行モデルによってシミュレーションを行うと， 出入口通過後歩行方向が直角に折れ曲がる場合に群集流 動係数が低下する。これを確認するため群集歩行実験を 行うと, 同様に流動係数が低下した。実験は以下の方法 で実施した。

1) 被験者は金沢工業大学および福井大学の建築学科学 生。

2）表一 3 に示す平面内を一度に $15 \sim 17$ 人の被験者が 歩行する実験を 3 回繰り返した。

3）実験は大学内の建物の教室および廊下で行った。適 当な平面形がない場合は，パネル等で壁面を構成して実 験空間を構成した。
4）各歩行実験ごとにネッグ部における通過人数と通過 所要時間を測定し，流動係数を計算して 3 回の試行の平 均值を求めた。

5）被験者は自然な歩行速度で歩行した。

被験者が自然に歩行して実験を行うと，全体的に流動 係数が高い值となった。これは被験者が全員 20 才台前 半の学生であるため, 一般の群集よりも歩行速度が速い ためと考えられる。そこで，被験者にゆっくりと歩行す るように指示し，直進の場合に流動係数が 1.5 程度にな るように調整して実験を行うと，やはり折れ曲がる場合 に流動係数が低下した。以上の実験結果を表一 3 にまと め,同一平面で行ったシミ゙ュレーション結果と比較する。 その結果以下のような流動係数低下の傾向と原因が考え られる。

1）出入口の幅が $80 \mathrm{~cm}$ の場合

歩行者は 1 人ずつ出入口から出て歩行するので，直進 の場合と折れ曲がる場合の流動係数の違いはほ之んぼ見 られない。

2）出入口の幅が $160 \mathrm{~cm}$ の場合

折れ曲がる場合に明らかな流動係数の低下が見られ た。歩行者が 2 人並んで出口から出ることができ，出口 を出て曲がる歩行者が後続の歩行者の障害となり，流動 係数が低下する。また，出口を出てから 2 方向に分岐す る場合は流動係数の低下がより大きい。これは，2 方向 に分岐するときに，動線の交差がときどき起こるからで ある。[例 EX 1， EX 4, EX 9]

·表一3 流動係数実験およびシミュレーション結果 ネック通過後直進する場合と曲がる場合の比較

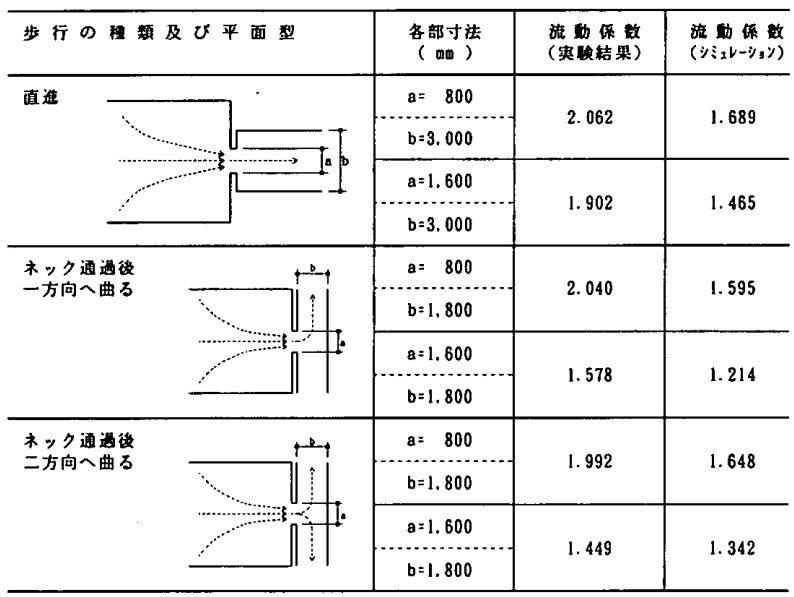

（3） ネック通過後の通路の有効幅が，ネック部分と同 じ場合は，通路が広くなっている場合より，流動係数が 低下する。これに関しても歩行実験を行い, 実際の群集 歩行とシミュレーショ.ン結果の両方で流動係数が低下す ることを確認した。ネック部通過後も群集密度が高いの で歩行速度に制限を受け，流動係数が低下すると考えら れる。実験方法は, 表一3の場合と同様で, 平面形は表 -4 に示すとおりりである。[例 EX 8] 
表一4 流動係数実験およびシミュレーション結果 ネック通過後の通路幅がネック部分と同じ場合

\begin{tabular}{|c|c|c|c|}
\hline 步行实的を行った平面型 & $\begin{array}{l}\text { 各部才法 } \\
(\text { on })\end{array}$ & 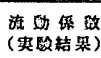 & 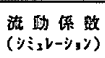 \\
\hline & $a=800$ & \multirow{2}{*}{1.844} & \multirow{2}{*}{1.625} \\
\hline \multirow{2}{*}{$\stackrel{\cdots \cdots \cdots \cdots}{\longrightarrow}\rfloor$} & $b=7.000$ & & \\
\hline & $a=1,600$ & \multirow{2}{*}{1.810} & \multirow{2}{*}{1.280} \\
\hline & $b=7.000$ & & \\
\hline
\end{tabular}

（4）通路から通路へ曲がるときは流動係数が落ちる。 通路幅が曲がる前後で同じ場合は，曲がるときにわずか に流動係数が低下するだけである。曲がった後の通路幅 が曲がる前よりも狭い場合は曲がる部分がネックとな り, 滞留が発生し流動係数が低下する。これに関しても 群集歩行実験を行い, 実際の歩行者の動きとシミュレー ション結果を比較すると, 一致した結果が得られた。(表 -5) [例 EX 8, EX 9]

表一5 流動係数実験およびシミュレーション結果 ネック通過後の通路が折れ曲がる場合

\begin{tabular}{|c|c|c|c|c|}
\hline 步行央的を行つた平面型 & $\begin{array}{l}\text { 各部寸法 } \\
\text { ( 凅) }\end{array}$ & $\begin{array}{l}\text { 勾定 } \\
\text { 位识 }\end{array}$ & 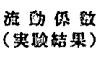 & 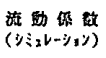 \\
\hline & \multirow{4}{*}{$\begin{array}{l}a=1.600 \\
b=1.600\end{array}$} & 1 & 1.058 & 1.280 \\
\hline & & 2 & 1.066 & 1.295 \\
\hline & & 3 & 0.874 & 1.140 \\
\hline \multirow{9}{*}{$\left.\frac{2}{3}\right] \rightarrow$} & & 4 & 0.965 & 1.280 \\
\hline & \multirow{4}{*}{$\begin{array}{l}a=1.600 \\
b=1.200\end{array}$} & 1 & 0.919 & 1. 280 \\
\hline & & 2 & 0.969 & 1.160 \\
\hline & & 3 & 1.158 & 1.545 \\
\hline & & 4 & 1.167 & 1.500 \\
\hline & \multirow{4}{*}{$\begin{array}{l}a=800 \\
b=800\end{array}$} & 1 & 1. 296 & 1.500 \\
\hline & & 2 & 1.145 & 1.565 \\
\hline & & 3 & 1.084 & 1.525 \\
\hline & & 4 & 1.005 & 1.565 \\
\hline \multirow{3}{*}{$\frac{2}{\left\lceil\frac{3}{b}\right\rceil}$} & \multirow{3}{*}{$\begin{array}{l}a=1.600 \\
b=800\end{array}$} & 1 & 0.935 & 1.281 \\
\hline & & 2 & 0.882 & 0.938 \\
\hline & & 3 & 1.065 & 1. 374 \\
\hline
\end{tabular}

（5）廊下の滞留が居室出口の流動係数に与える影響

1) 階段 1 つに対して出口の数が多く, 廊下面積が少な い場合［例 EX 4 (80.00 秒) 階段 2 の前の廊下に 4 つ の居室出口が面している。(困一6)]

2）階段室入口の狭い幅が歩行速度を低減し，そのため 発生する滞留の影響により, 出口から出られなくなる場

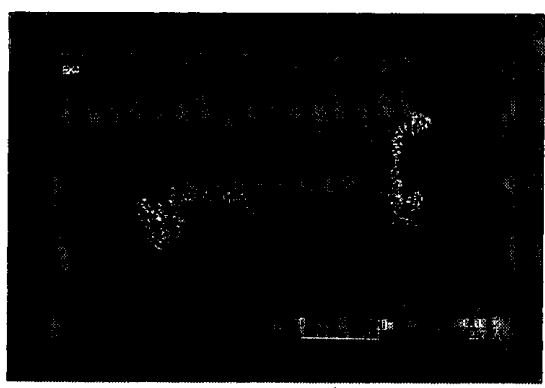

凹下の斿曰により居室迅日加 影四を受ける。

图一6 シミュレーション例 (EX 4 80.00 秒) $-56-$
合 [例 EX 1（45.00 秒）出口 2 加階段 A への廊下]

3）居室出口前の通路に滞留または高密度の群集流があ りここれに合流する場合には流動係数が低下する。

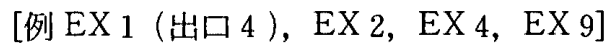

3.3 当シミュレーションモデルによる滞留密度と群集 歩行密度・群集歩行速度

避難先の階段室または居室の出入口幅が狭いため滞留 が起こり始め, 歩行密度が上がれば，歩行速度が落ちる ので, 居室から廊下への出口の流動係数が落ち始める。 防災評定のようにいきなり 3 人 $/ \mathrm{m}^{2}$ の滞留が発生し, こ の滞留部分が広がっていくのではなく、シミュレーショ ンでは徐々に群集流の滞留の密度が高まる。長時間滞留 が続くと, 滞留密度は $0.30 \mathrm{~m}^{2} /$ 人 $\left(3.31\right.$ 人 $\left./ \mathrm{m}^{2}\right)$ 程度に なる。図一7にシミュレーション例において, 滞留が発 生している様子を示す。

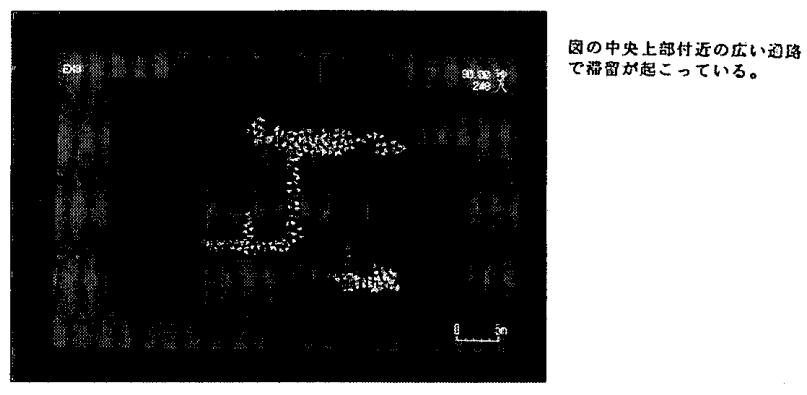

図一7 シミュレーション例（EX 3 90.00 秒)

「新・建築防災計画指針」では滞留人数の評価の部分 （p.125）で，「滞留に必要な面積は，鄉下などの第一 次安全区画では群集歩行密度を考慮して 1 人当たり 0.3 $\mathrm{m}^{2}$ とする」としている。したがってモデルによるシミュ レーション結果はモデルがこの面で「新・建築防災計画 指針」と一致していることを示している。

当モデルのシミュレーション結果から測定した歩行速 度と密度の例を挙げると以下のとおりである。

EX 145.00 秒前後 事務室 1 の出口 2 通過後の廊下 を歩行中の歩行者

歩行密度 約 1.45 人/ $\mathrm{m}^{2}$, 歩行速度 $0.84 \mathrm{~m} /$ 秒

EX 390.00 秒前後 会議室 $1,2,3$ に面する広い廊 下で滞留している歩行者

歩行密度 約 3.00 人 $/ \mathrm{m}^{2}$, 歩行速度 $0.28 \mathrm{~m} /$ 秒

これらの値は J.J. Fruin の歩行速度と歩行者占有面 積の関係を良く満足している。[文献 9） p.49 図 3-2]

3.4 経路のとり方のシミュレーション

防災評定避難計算では, 避難者は最寄りの出口から避 難することとされているが，これに忠実に従うと，近接 した居室出口や階段室入り口の一方にのみ歩行者が向か い, 一方は混雑するが，他方は䦥散としているような非 現実的な状況が生じる。[例 EX 1, EX 4, EX 8]

EX 8 の平面を用いて避難経路の設定を変更した例を 
以下に示す（図一8，図一9）。この例による避難時間は 表一6のとおりである。当モデルによると，このような 避難経路変更の検討も容易に行える。

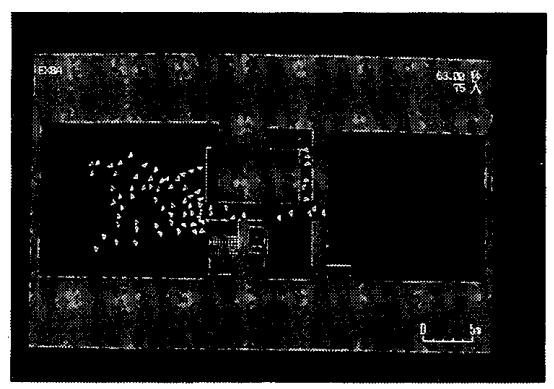

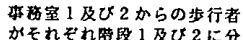
がそれそれ䑀段 1 及び 2 に分 加て進方

図一8 シミュレーション例 (EX 8 A

63.00 秒)

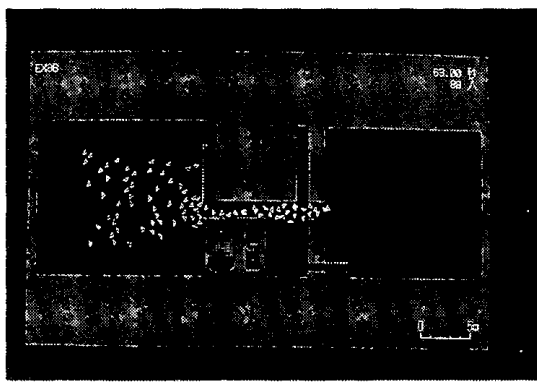

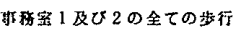

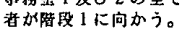

图一 9 シミュレーション例 $(\mathrm{EX} 8 \mathrm{~B}$

63.00 秒

表一6 避難時間の判定（EX8の避難経路変更）

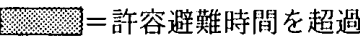

\begin{tabular}{|c|c|c|c|c|c|}
\hline \multirow{2}{*}{ 击 释 路 } & \multirow{2}{*}{ 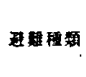 } & \multirow{2}{*}{ 室 名 } & \multirow{2}{*}{ 出口 } & \multicolumn{2}{|c|}{ 起時間（知） } \\
\hline & & & & 形容值 & シンルレータタ \\
\hline \multirow{6}{*}{ 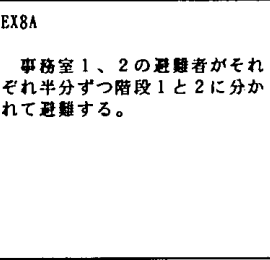 } & \multirow{2}{*}{ 居至进韧 } & 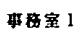 & 1 & 31.0 & $* 13422^{\circ}$ \\
\hline & & 事坫室 2 & 2 & 30.0 & +304 \\
\hline & \multirow{2}{*}{ 的下些期 } & 陉目 & 1 & \multirow{2}{*}{92.0} & 64.3 \\
\hline & & 䧄 & 2 & & 74.2 \\
\hline & \multirow{2}{*}{ 䧄进 } & 俻 & 1 & \multirow{2}{*}{185.0} & 97.2 \\
\hline & & 陼 & 2 & & 106.6 \\
\hline \multirow{4}{*}{ 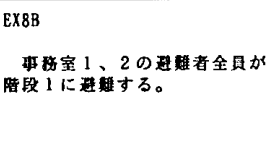 } & \multirow{2}{*}{ 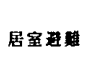 } & 事暆富 1 & 1 & 31.0 & $45690=$ \\
\hline & & 転辟室 2 & 2 & 30.0 & $1192^{1} t^{2}$ \\
\hline & 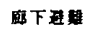 & 猎 & 1 & 92.0 & 87.7 \\
\hline & 陆用 & 陵 & 2 & 185.0 & 120.1 \\
\hline
\end{tabular}

\section{5 当シミュレーションによる附室の滞留状況}

「新・建築防災計画指針」(p.140) に述へているよう に，階段入り口之附室入り口を結ぶ動線外に歩行者が溢 れて滞留することは, 当シミュレーションでは磁場を想 定して歩行者の動きを制御しているのであり得ない。図 -10の例では歩行者の軌跡を点線で表示している。左

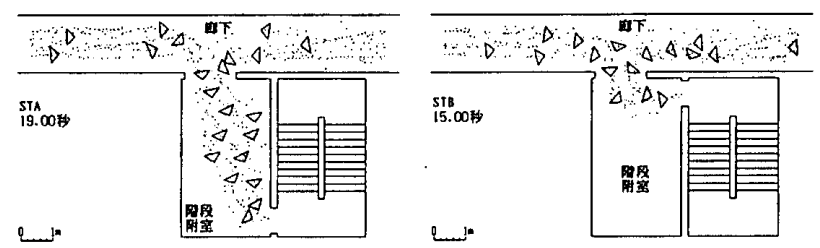

図一10 階段附室におけるシミュレーション例
右の図を比較すると, 附室の有効面積の違いは明らかで ある。

以上により, 当群集歩行シミュレーションによる避難 性能の検討方法の有効性を立証した。防災評定避難計算 に基づく避難時間および滞留面積の検討が可能であるば かりでなく，防災評定避難計算では扱っていない事項に 関しても検討可能であることをシミュレーション結果に より示した。さらに実際の群集歩行実験によってそれを 確認した。シミュレーション結果により, 視覚的に計画 上の問題点を容易に把握可能であり, 設計へのフィード バックにも適していることを示した。

\section{結 語}

シミュレーションの結果とそれに基づく実際の歩行実 験の結果，以下の各項が明らかになうた。

（1）当モデルのシミュレーションにより避難全体の時 間的・空間的状況を動画として把握できるようになり， 危険な時刻や場所の発見, 経路の変更, 時差避難等を考 慮しながら最適な避難計画を求めることができる。これ により当モデルは，「新・建築防災計画指針」の関題点 として指摘された設計へのフィードバック ${ }^{109}$ のために は，現防災評定避難計算より適していると思われる。 （2）防災評定避難計算にはない, 避難中の流動係数の 低下が以下のように起こることが分かり，それらは実際 の歩行実験でも確認された。流動係数の低下はすべての 避難時間の増大につながり，特に居室避難時間に重大な 影響を与える。(表一1，表一2)

1）広い居室で避難開始後しばらくは出口への到達者数 が少なく，流動係数は低い状態から始まり，そのため居 室避難時間は長くなる。

2）出入口通過後折れ曲がる場合。出入口の幅により， 流動係数の低下が異なる。幅が $80 \mathrm{~cm}$ の時は 1 列で歩 行するため，流動係数に変化がない。幅が $160 \mathrm{~cm}$ にな ると曲折時に 2 人が交差する場合が起こるため，流動係 数が低下する。このとき左右の 2 方向に曲がるときは低 下が著しい。1 方向のみに曲がるときも低下する。

3）同一幅員の通路が直角に曲がるときは, 屈折直後, やや流動係数が低下するが，その屈折を過ぎると，すぐ にもとの流動係数に戻る。

4）防災評定避難計算では気付き難いが，居室出口前の 通路に滞留または高密度の群集流があると，出口の流動 係数が低下する。

5) ネック (出口) 通過後の通路幅が, 出口より広くなつ ている場合より, 出口と同じ幅の場合のほうが流動係数 が低い。

（3）滞留密度と速度の関係も実測値”に近い。またほ とんど停滞してしまったときの滞留密度は防災評定避難 計算の值に近い。 
（4）廊下の群集歩行密度が高くなるにつれて，徐々に 歩行速度が落ち，それが居室出口の流動係数を低下させ る点が防災評定避難計算とは異なる。

以上により当モデルによる避難シミュレーションが避 難計画上の問題点を指摘するのに有効であることを明ら かにした。防災評定避難計算に基づく避難時間および滞 留面積の検討に対する有効性に加え，防災評定避難計算 では扱っていない事項に関しても検討可能であることを シミュレーション結果および歩行実験結果により示し た。このシミュレーション結果によれば，視覚的に計画 上の問題点を容易に把握可能であり, 設計へのフィード バックにも適している。

\section{参慗文献}

1) 建設省住宅局建築指導課監修：新 - 建築防災計画指針 1985 年版, 日本建築センター, 1985 年

2) 吉田克之：新建築学体系 12 建築安全論 5.2 .4 避難行 動の予測, 彰国社, pp. 260 268,1983 年

3）岡崎甚幸：建築空間における歩行のためのシミュレー ションモデルの研究 その1 磁気モデルの応用による歩 行モデル, 日本建築学会論文報告集, 第 283 号, 1979 年 9 月, pp. 111 117

4）岡崎甚幸：建築空間における歩行のためのシミュレー ションモデルの研究 その 2 混雑した場所での歩行, 日
本建築学会論文報告集, 第 284 号, pp. $101 \sim 110,1979$ 年 10 月

5）岡崎甚幸：建築空間における歩行のためのシミュレー ションモデルの研究，その 3 停滞や火災を考虑して最短 経路を選ぶ歩行, 日本建築学会論文報告集, 第 285 号, pp. 137 144，1979年11月

6）岡崎甚幸, 山本 親：建築空間における歩行のためのシ ミュレーションモデルの研究, その 4 群集歩行の透視図 による表現, 日本建築学会論文報告集, 第 299 号, pp. 105 113，1981 年 1 月

7）岡崎甚幸, 松下 瞈：建築空間における歩行のためのシ ミュレーションモデルの研究，その 5 探索歩行及び誘等 標による歩行, 日本建築学会論文報告集 第 302 号, pp. $87 \sim 93,1981$ 年 4 月

8）松下 聡, 岡崎甚幸: 巨大迷路歩行実験による探索步行 のためのシミュレーションモデルの研究, 日本建築学会 計画系論文報告集, 第 429 号, pp. 51 59, 1991 年 11 月

9) J. J. Fruin, PEDESTRIAN Planning and Design, Ka jima Institute Publishing Co. Ltd. 歩行者の空間, 長島 正充 (訳), 鹿島出版会 1974 .

10）日本建築学会建築語画委員会：安全計画 $I$, 安全計画の 視点 2-3 C, 避難計算の考え方, pp. 45 50, 1981 年 10 月

(1991 年 12 月 9 日原稿受理, 1992 年 4 月 8 日採用决定) 